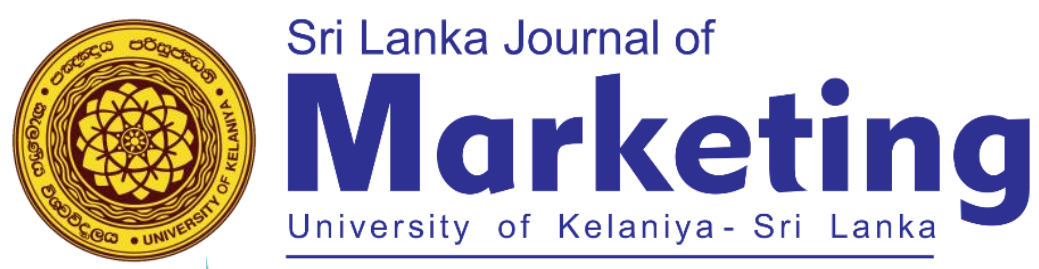

\title{
The Impact of Marketing Research Practices on Financial Performance: Study of Small and Medium Enterprises in Sri Lanka.
}

\begin{tabular}{|c|}
\hline Pushpasiri T.K. \\
Finance Commission of Sri Lanka \\
thisarakasun@gmail.com \\
Dharmadasa V.P. \\
Finance Commission of Sri Lanka \\
virajpriyankara7@ gmail.com
\end{tabular}

\begin{abstract}
Marketing research practices have been identified as one of the important key ingredients for superior performance and global competitiveness in Small and medium enterprises (SMEs). The success or failure of SMEs is said to rests in part on the nature and types of marketing research practices they employ. The study was carried out with four dimensions under the marketing research practices as price-related practices, product-related practices, maintain customer relationship related practices and promotion related practices to understand the relationship with financial performance in SMEs. Data were collected using questionnaires from 200 respondents in the SMEs. Based on the findings of the study, it concluded that there is a moderate positive relationship between marketing research practices and financial performance. As well as all the dimensions of the marketing research practices are significant predictors of the financial performance while price-related practices and product-related practices are major among them. According to the results of simple regression analysis, marketing research practices were found to have a positive impact on financial performance.
\end{abstract}

Keywords: Financial Performance, Marketing Research Practices, Small and Medium Enterprises 


\section{INTRODUCTION}

Small scale business plays a major role in developed and developing counties' economic development. It contributes largely to the GDP by participating in the mainstream economy, becoming a source of income to a substantial portion of the population by providing decent jobs (Department of Census \& Statistics, 2014). But in Sri Lankan context, small business owners are facing greater challenge in the modern businesses environment. The causes can be identified as tough competition, rapidly changing new technologies and globalization of products and services. Comparing to the other countries in the region, the contribution of SMEs to the Sri Lankan economy is very low (Gamage, 2003).

The small industries are the major source of employment and production of foods in rural areas of Sri Lanka (Vijayakumar, 2013). So all the governments came into power since independence in 1948, have identified the importance of developing this sector (Gamage, 2003). Small and medium business marketers may consider advertising, segmentation, targeting, pricing, customer orientation and seeking competitive advantage apply to small and medium business as marketing practices. (Awan \& Hashmi, 2014). In this new economic era, we are moving towards favoring of small and medium firms. Achieving accelerated performance in SMEs demands their marketing research practices to be entrepreneurially and properly carried out and correctly implemented at the right time and in the right proportion.

The definition of small enterprise varies because of the diversity of small business. Every definition is subject to criticism and there is no generally accepted definition. A small business is privately owned and operated business and typically has a small number of employees (Gajanayake,2010). The definition of a small business is determined according to the number of employees i.e. Small businesses have less than 10 employees and medium business have less than 100 employees (Department of Census \& Statistics, 2014).

Market research is the process of gathering information about the market, customers, and competition (Asha, 2017). It can help to learn more about what people want to sell product or service to; what they want, need, believe or how they act. It will allow to identify and analyze the market need, size, and competition. It can be used to determine the feasibility of product or service, identify how to promote product or service and develop a competitive strategy (Davies, 2000). A proper financial performance provides a full range of accurate and reliable information to compare the actual performance of the company (Hendricks \& Singhal, 2001). Financial information (i.e. return on investments, return on equity, growth of sales, profitability, etc.) is the most extensively explicit and valid information among the other performance dimensions (Aktan \& Bulut, 2008). Based on what came in above the current study seeks to demonstrate the impact of marketing research practices on financial performance. 


\subsection{Research Problem}

As mentioned earlier, comparing to the other countries in the region, the contribution of SMEs to the Sri Lankan economy is very low (Gamage, 2003). According to the Department of Census (2014), Sri Lanka doesn't have generally accepted criteria for SMEs. Most studies on marketing research practices have always focused on large firms in developed markets and economies. i.e. Bulut (2013) in the textiles industry, Tandoh \& Sarpong (2015) in the automobile industry. But for the small or medium scaled businesses it is difficult to find studies related to this topic. The researcher has selected Rathnapura district to conduct this study where most of the researchers conduct studies on this topic for large scaled businesses in Western Province. i.e. the study conducted by Gajanayake (2010) in Gampaha District, western province, the impact of marketing strategies and behavior on Business Growth. Even though marketing research information identified as key for business success, there have been few empirical studies that examine the link between marketing research activities and business performance (Bulut, 2013). According to Nthenge (2016), the study of marketing practices in SMEs has been recognized as a problematic area for researchers for over 20 years.

Similar studies may not have the same framework, similar marketing research practices, and financial performance variables. Although some researches have been conducted on the effect of marketing research practices on the financial performance of SMEs (Mba \& Emeti, 2014), most of these studies were done many years ago. With the changes in environment, globalization, technology business and even marketing research practices, there is a need to conduct similar researches that reflect the reality of the present time.

While there is substantial evidence documenting the effects of marketing research activities on marketing performance (Bulut, 2013), customer satisfaction and firm performance (Moses, 2015), there is less number of researches that examine how marketing research practices affect small and medium industry performance and the variables that account for this relationship Nthenge (2016). Providing a better understanding of the role of marketing research practices of SMEs on financial performance is the primary focus of this study. This research investigation seeks to address the relationship between marketing research practices of SMEs with the financial performance of their firms. One form of SMEs success is addressed by this research as financial performance. Such as, this effort is to identify what is the impact of marketing research practices on financial performance in SMEs.

Although SMEs do not correctly do their marketing research practices regularly, it is essential to maintain growth in their financial performance. So using this study SMEs can obtain sufficient knowledge about the impact of marketing research practices on financial performance. So, in this study, the main research problem was to measure 'Is there any influence from marketing research practices on Financial Performance with special reference to SMEs in Sri Lanka' 


\subsection{Research Objectives}

$\checkmark$ To identify the type of marketing research practices which are significant for financial performance in SMEs in Rathnapura District.

$\checkmark$ To examine the relationship between marketing research practices and financial performance in SMEs in Rathnapura District.

$\checkmark$ To examine the impact of marketing research practices on financial performance in SMEs in Rathnapura District.

\subsection{Significance of the Study}

Most of the small and medium enterprises in Sri Lankan context use marketing research practices which is most important to the financial performance. Although SMEs do not correctly do their marketing research practices regularly, it is essential to maintain growth in their financial performance. So using this study SMEs can obtain sufficient knowledge about the impact of marketing research practices on financial performance in small and medium enterprises. When a business expects to introduce a product or service or enhance those, market research is generally performed. Also, market researchers are conducting when there is a need to expand the business geographically or when there is a need to identify a different or new target market. SMEs can maintain such a position when a good number of strategies including the formulation and application of appropriate entrepreneurial marketing research practices are put in place at the right time and in the right proportion to exert a positive effect on financial performance.

Findings of this research are important for the policymakers who will be interested in facilitating the expansion of SMEs. Here, the relevant authorities can take necessary actions to promote facilities to increase the financial performance of SMEs. This study will provide a guideline for future researchers who are interesting to do research relevant to this area. Moreover, new researchers can expand this study by advancing the variables.

\section{LITERATURE REVIEW}

Many researchers have considered small businesses as the backbone of any country's economy. Because small business needs relatively less capital and infrastructure but plays an important role in any economy through generating of employment, contributing to the growth of GDP, embarking on innovations and stimulating of other economic activities (Gamage, 2003). In Sri Lanka, more than 80\% of businesses run by Small and medium enterprises which are mainly in foods processing, manufacturing, and construction field. In addition, they are supplying about 35 percent of employment and about 20 percent of total industrial value addition (Galagoda, 2008). 
Marketing research is the application of the scientific method in search of the truth about marketing phenomena (Cateora \& Graham, 2005). According to Harvad (2007), marketing research is the systematic gathering, recording, and analysis of data about issues relating to marketing products and services. This can be considered as a systematic approach that involves data collection and data analysis on any relevant marketing-related issues. In marketing, research is used for a variety of purposes including obtaining insights into customer attitudes and beliefs, measuring customer satisfaction, ascertaining the effectiveness of advertising, etc. (Rambocas \& Gama, 2013). Ebitu \& Tom (2016) used product quality, marketing communication, and relationship marketing to examine the act of three marketing strategies on the performance of selected SMEs. That study revealed that the significant relationship of both the product quality and relationship marketing with organizational profitability. However, the marketing communication strategy does not have a significant impact on the growth of SMEs. The following section reviews the literature pertaining to the type of market research practices and traces the development of the typology used to classify market research practices in this study.

Product-related practices - Product research encompasses all applications of marketing research that seek to develop product attributes that will add value for consumers, (Zikmund \& Babin, 2010). Product research helps to provide an effective assessment of the strengths and weaknesses of a product or service in comparison with competitors' products or services. It also provides information on the appropriate packaging of a product, helping to design it in such a way as to promote the image of the product (Tony \& Jamieson, 2012). Product influences to have a significant impact on business performance (Adewale et al., 2013). Anyhow, it is important the product quality to be consistent with the other elements of the marketing mix. For example, "a premium based pricing strategy will require a quality product to support the price tag" (Learnmarketing, 2015). The researcher used some product quality-related practices (Lakhal \& Pasin, 2008) in the questionnaire as market research practices. i.e. test the product quality, market situation and method of development before introducing a product, providing high-quality product compared to the competitors.

Promotion Related Practices - Promotion research investigates the effectiveness of advertising, premiums, coupons, sampling, discounts, public relations, and other sales promotions. However, among all of these, firms spend more time, money, and effort on advertising research (Zikmund \& Babin, 2010). Adewale et al. (2013) revealed that the relationship between promotion consideration and business performance is significant, but they are inversely related. This may be due to the consumer perception that heavily promoted products could be problematic products of poor quality, with passed expiry dates, and from clearance stocks. Promotion research can provide information on which medium is most likely to reach the target audience for specific campaigns. It also provides information about what messages are most likely to appeal to the target audience. (Tony \& Jamieson, 2012). Tandoh \& Sarpong (2015) conducted a study on automobile industries and revealed that the impact of sales 
promotion on organizational performance is intense. The researcher has used different promotionrelated practices as market research practices. viz. competitors' promotion strategies, analyze promotion strategies monthly basis, after-sale analysis.

Price Related Practices - Most organizations conduct pricing researches (Zikmund \& Babin, 2010). Pricing analysis addresses consumer quality perceptions by its terrible nature. an excellent deal of research addresses consumer reactions to low costs and documents the fact that, in quite a few instances, prices can really be too low. In other words, sales can actually decrease with lower prices instead of increasing, (Zikmund \& Babin, 2010). According to Tony et al (2017), pricing policies influence the profitability i.e. financial performance of a business. In the questionnaire, the researcher used questions for price related practices such as perfect price after studying the market trends, competitors' pricing policies, forecasting future pricing and discounts.

Maintain Customer Relationship Related Practices - Customer market research can produce quantitative facts about particular markets and market segments - for example, the size of the market both in terms of unit sales and value. When this data is collected over time it allows one to identify trends and helps to predict future sales (Tony \& Jamieson, 2012). The goal of relationship marketing (or customer relationship marketing) is to form sturdy, even emotional, customer connections to a brand which will result in current business, free viva-voce (word of mouth) promotion and information from customers which will generate leads (Rouse, 2015). Waskito (2018) identified that customer relationship management (CRM) influence financial performance and increase customer retention. Another study conducted by Bhavani (2015) identified that CRM practices are useful to increase profitability. Also, businesses are losing 17 percent of their customers mainly because the customers are not aware of CRM Practices provided by the businesses.

According to Dushi et al. (2019), entrepreneurs have to replace traditional marketing practices with new innovative ideas and actions when traditional principles are unsuitable for SMEs. The number of employees and financial performance viz. profit, turnover, return were based for business success according to the traditional measures. (Forsaith \& Hall, 2000). Financial firm success is measured in broad categories of growth and business volume. The three items used to measure growth include (1) perceived growth in market share; (2) change in cash flow; and (3) sales growth. The three items used to measure business volume include (1) earnings, (2) sales, and (3) net worth (Chandler \& Hanks, 1993). Asha (2017) found that marketing research practices have an influence on the performance of cement companies in Kenya. Pricing, Product, Promotion, Customer service, Distribution and Process researches were used in the study. Also, Raguragavan (2001) had identified the relationship between market research and business performance. Most of the marketers studied and identified the positive relationship between marketing research practices and business performance. (Hooley \& Lynch, 1985; Braker \& Black, 1988). Bulut (2013), found the level of use of marketing research practices affect 
profitability and competitive standing. However, by conducting a study on SMEs in Sri Lanka, Gajanayake (2010), revealed that there is no significant impact of marketing strategies on their business growth. Nthenge (2016) conducted a study on the clothing and footwear industry's SMEs and found only the advertising has a significant impact on a firm's performance. Product, Place, Pricing have not had relationships with the firm's performance.

\subsection{Theoretical Framework}

The conceptual framework depicted in figure 2.1 developed based on the literature survey and the requirement of the study. Independent variable is marketing research practices and the dependent variable is financial performance.

Figure 2.1. Conceptual Framework of the Study

Independent Variable

Marketing Research Practices
Product related practices
Promotion related practices
Price related practices
Maintain customer relationship related
practices

Source: Researcher developed

\subsection{Variable Selection and Hypothesis Development}

"Marketing Research Practices" is the independent variable of this research and key dimensions of Marketing Research Practices were identified through an extensive search of previous research articles. Most of the companies adopt $4 \mathrm{ps}$ (price, place, promotion, product) as their marketing strategy for financial performance. (Asha, 2017). Instead of place, relationship marketing practices were used by the researcher since there are previous studies which confirmed the relationship between CRM and financial performance. (Waskito, 2018 \& Bhavani, 2015). After reviewing previous research articles, researcher adjusted the variables with the current requirement. Dimensions are, Product related practices ((Learnmarketing (2015) and Lakhal \& Pasin, (2008)), Promotion-related practices (Tandoh \& Sarpong (2015)), Price related practices (Tony et al (2017) and Maintain customer relationship related practices.

Hypothesis 1: H0 - There is a negative relationship between Marketing Research Practices and Financial Performance in SMEs of Sri Lanka 
Hypothesis 2: H1 - There is a positive relationship between Marketing Research Practices and Financial Performance in SMEs of Sri Lanka

The process of operationalization makes the variables measurable in a quantitative manner. The quantitative form of data collected by questionnaires and then analyzed to see whether the data support for hypothesis or not. 5 closed ended questions were used to gather the demographic and business details. 25 scaled based questions for both dependent and independent variables used to see the results of the relationship. For measuring the 5 dimensions in the study, some indicators were used as expressed in table 2.1.

Table 2.1. The dimension and indicators of marketing research practices

\begin{tabular}{|c|c|}
\hline Dimension & Indicator \\
\hline \multirow{3}{*}{ Product Related Practices } & Product Testing \\
\hline & Modification studies \\
\hline & Introduction new product \\
\hline \multirow{3}{*}{ Promotion Related Practices } & Consider promotion results \\
\hline & Collecting information \\
\hline & Consider competitors promotion strategy \\
\hline \multirow{4}{*}{ Maintain customer relationship } & Respond to Social Pressures \\
\hline & Assessment of customer preference \\
\hline & Study purchasing pattern \\
\hline & Friendly and chatting \\
\hline \multirow[t]{4}{*}{ Price Related Practices } & Market price trend \\
\hline & Price change of competitors \\
\hline & Study future price trend \\
\hline & Price incentive and discounts \\
\hline \multirow[t]{5}{*}{ Financial Performance } & Growth market share \\
\hline & Sales growth \\
\hline & Change in cash flow \\
\hline & Profitability \\
\hline & Total revenue \\
\hline
\end{tabular}

Source: Survey data 2019

\section{RESEARCH METHODOLOGY}

The research study was focused on explaining the impact of marketing research practices on financial performance of SMEs. The population of the study was small and medium business owners in Sri Lanka who are using marketing research practices. 
According to the Census Department (2014), 60\% of the small-scaled establishments and $47.9 \%$ medium-scaled establishments out of the total in Sri Lanka have scattered in the rural areas. Table 3.1. shows the no. of establishments and no. of people engaged in SMEs in some districts of Sri Lanka. This has taken one district from one province.

Table 3.1. No of SMEs and People in Some Districts

\begin{tabular}{|l|l|l|}
\hline District & No of SMEs & No.of People Engaged \\
\hline Colombo & 19,311 & 239,619 \\
\hline Kandy & 6,144 & 60,836 \\
\hline Galle & 3,498 & 40,954 \\
\hline Jaffna & 2,389 & 22,411 \\
\hline Ampara & 1,558 & 14,213 \\
\hline Kurunegala & 5,728 & 59,040 \\
\hline Anuradhapura & 2,623 & 23,528 \\
\hline Badulla & 2,101 & 23,551 \\
\hline Ratnapura & 3,887 & 43,050 \\
\hline
\end{tabular}

By analyzing the 25 districts and 9 provinces of Sri Lanka, the Western province has a large number of SMEs and employees. It can be clearly identified that Sabaragamuwa Province is in the middle of the list. But the number is high in the Ratnapura District compared to Kegalle. The researcher selected Ratnapura since it has the middle number of SMEs and entrepreneurs by comparing the other districts of Sri Lanka. The economic city of Sri Lanka is Colombo. Most of the studies are conducted based on there (Gajanayake, 2010). However, in Sri Lankan's economy, a considerable amount of income is generated by Sabaragamuwa area of Sri Lanka. New entrepreneurship opportunities are being developed in this area with the development of some industries like tourism (Department of Census and Statistics, 2014).

Data were collected based on primary and secondary sources. 200 questionnaires were distributed among the small and medium business owners throughout the Rathnapura district to collect primary data. Closed ended questions and scale-based questions were used in the questionnaire. Closed-ended question were used to get specific information, since the person who is going to answer, would have few choices. Scale based questions were used to test the impact of marketing research practices on financial performance. For that researcher used five-point Likert scales that have ranked from positive to negative.

The sample of 200 owners drawn from the target population consisted of small and medium business owners from multiple firms located across the Rathnapura district. The study used the systematic stratified sampling technique in coming up with a sample of 200 SMEs. The goal of systematic stratified 
random sampling is to achieve the desired representation from various subgroups in the population (Nthenge, 2016). The sample (200) was divided among the divisions in Rathnapura district as subgroups (strata). This sampling technique facilitated the researcher to collect data without facing inconveniences and reducing bias. 40 questionnaires were distributed among the SME owners in Eheliyagoda and Kuruwita devisions as a pre-test of the questionnaire. According to the analysis, all the questions were internally consistent since the alpha value is higher than 0.6 in every dimension.

Table 3.2. The Sampling distribution of small business

\begin{tabular}{|l|l|l|}
\hline Division & No of SMEs & Sample \\
\hline Eheliyagoda & 310 & 16 \\
\hline Kuruwita & 468 & 24 \\
\hline Rathnapura & 608 & 32 \\
\hline Imbulpe & 284 & 22 \\
\hline Balangoda & 419 & 20 \\
\hline Opanayaka & 480 & 18 \\
\hline Pelmadulla & 487 & 24 \\
\hline Elapatha & 200 & 10 \\
\hline Nivithigala & 212 & 10 \\
\hline Embilipitiya & 419 & 124 \\
\hline Total & 3887 & 200 \\
\hline
\end{tabular}

Source: Department of Census and Statistics $(2013 / 2014)$

\section{FINDINGS}

The inter item consistency reliability has been examined with Cronbach's Alpha test. The results of Cronbach's alpha test are given in the Table 4.1, which suggest that the internal reliability of each instrument is satisfactory.

Table 4.1 Cronbach's Alpha Coefficients

\begin{tabular}{|l|l|}
\hline Dimension & Cronbach's Alpha \\
\hline Financial performance & 0.782 \\
\hline Marketing research Practices & 0.873 \\
\hline Product related practices & 0.887 \\
\hline Promotion related practices & 0.886 \\
\hline Maintain customer relationship related practices & 0.810 \\
\hline Price related practices & 0.855 \\
\hline
\end{tabular}

Source: Survey data 2019

Hair et al (1998) have suggested that exploratory research could reduce the value to 0.60 as the minimum acceptable limit for the Conbach's alpha. According to the Cronbach's Alpha test, all the 
values are greater than 0.60 which surpass the acceptable value. It seems that the questions used in the questionnaire are good measurements of measuring the independent variable i.e. marketing research practices. Under the descriptive statistics analysis it looks at the mean and the standard deviation value of each variable in the research. This research study is comprised of 200 respondents (individuals) that are important to identify the nature of the research study sample. When it comes to the demographic factor of the research study, it includes Gender, Age level, Kind of business, Number of employees and Duration of business.

\subsection{Descriptive Statistics Analysis}

Descriptive statistics refer to the descriptive coefficients which sum up a given data set of the study variables that can be either a representation of the entire population or a sample of it. Simply, it illustrates the methods to summarize large sets of quantitative/numeric data of the research study. It also considers individual variables and this type of analysis is called as univariate analysis. Under the descriptive statistics analysis it looks at the mean and the standard deviation value of each variable in the research.

\section{Analysis of Scale Based Questions}

By analyzing the scale-based questions, respondents' view on dimensions of marketing research practices and financial performance can be identified.

Table 4.2 Descriptive Statistics

\begin{tabular}{lccccc}
\hline \multicolumn{5}{c}{ Descriptive Statistics } \\
& $\mathrm{N}$ & Minimum & Maximum & Mean & Std. Deviation \\
\cline { 2 - 6 } & & & & & \\
Independent Variable & & & & & \\
(MRP) Dimensions & 200 & 1.00 & 3.00 & 1.51 & .31234 \\
Product related practices & 200 & 1.00 & 4.00 & 1.78 & .41132 \\
$\begin{array}{l}\text { Promotion related practices } \\
\text { Maintain customer relationship } \\
\text { related practices }\end{array}$ & 200 & 1.00 & 4.00 & 1.62 & .39271 \\
Price related practices & 200 & 1.00 & 3.00 & 1.67 & .42134 \\
Dependent Variable (FP) & & & & & \\
Financial Performance & 200 & 1.00 & 3.00 & 1.82 & .49311 \\
Valid N (listwise) & 200 & & & & \\
\hline & Source: Survey data 2019 & & & \\
\end{tabular}

According to table 4.2, mean value of the dimensions of marketing research practices are closer to 2.0. Therefore, we can conclude that entrepreneurs are using these dimensions as their marketing research 
practices. Further, it can be identified that financial performance of an SME increases with the marketing research practices because of the mean value of financial performance is closer to 2.0.

\subsection{Hypothesis Testing}

Using the Pearson's correlation with two - tailed test of significance, the Correlation analysis has been made to investigate any relationship between the independent variable- marketing research practices and dependent variable-financial performance can be summarized as follows. Pearson's correlation was used because the researcher wanted to find the linear relationship between the two variables. Also, to find out whether there is a positive/negative significant relationship between two variables.

Table 4.3 Correlations between marketing research practices and financial performance

\begin{tabular}{|c|c|c|c|c|c|c|}
\hline & & FP & Prod & Prom & CRM & Price \\
\hline \multirow[t]{2}{*}{ FP } & Correlation Coefficient & 1.000 & $.450 * *$ & $.290 * *$ & $.325^{* *}$ & $.366^{* *}$ \\
\hline & Sig. (2-tailed) & & .000 & .000 & .000 & .000 \\
\hline \multirow[t]{2}{*}{ Prod } & Correlation Coefficient & $.450 * *$ & 1.000 & .314 & -.087 & -.158 \\
\hline & Sig. (2-tailed) & .000 & . & .211 & .170 & .130 \\
\hline \multirow[t]{2}{*}{ Prom } & Correlation Coefficient & $.290 * *$ & .314 & 1.000 & $.213^{* *}$ & $.115^{* *}$ \\
\hline & Sig. (2-tailed) & .000 & .211 & . & .001 & .001 \\
\hline \multirow[t]{2}{*}{ CRM } & Correlation Coefficient & $.325^{* *}$ & -.087 & $.213^{* *}$ & 1.000 & $.126^{* *}$ \\
\hline & Sig. (2-tailed) & .583 & .170 & .001 & . & .001 \\
\hline \multirow[t]{2}{*}{ Price } & Correlation Coefficient & $.366^{* *}$ & -.158 & $.115^{* *}$ & $.126^{* *}$ & 1.000 \\
\hline & Sig. (2-tailed) & .000 & .130 & .001 & .001 & \\
\hline
\end{tabular}

According to the results of the Pearson's correlation shown in table 4.2, there is a moderate positive significant correlation between marketing research practices and financial performance. The correlation is significant at $0.01(2$ - tailed) as p value is 0.000 , and as the Coefficient $(r)$ is 0.505 , it is found as a moderate positive correlation.

Table 4.3 depicts the correlation value and the significance value of the variables between dependent variable (Financial Performance) and independent variable (Marketing Research Practices) i.e. Product related, Promotion related, CRM related and price related marketing practices.

In the variables between product related practices and Job financial performance, it can be identified that $\mathrm{p}$-value is 0.000 and correlation coefficient is 0.450 . Since p-value is lower than 0.05 the desired significance level, the null hypothesis should be rejected at $5 \%$ level of significance. Because of the 


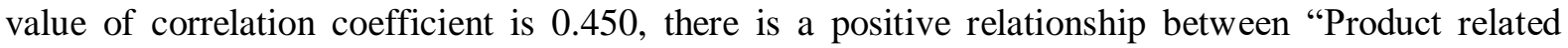
practices" and "Financial performance". It is clear that the positive relationship between the rest of the independent variable's dimensions and dependent variables, since the $p$ values are 0.000 and correlation coefficients are $0.290,0.325$, and 0.366 respectively.

As shown in figure 4.1, the scatter plots between MRP and FP indicate a positive correlation with scattered points around a straight line.

Figure 4.1: Scatter plots between MRP and Financial Performance

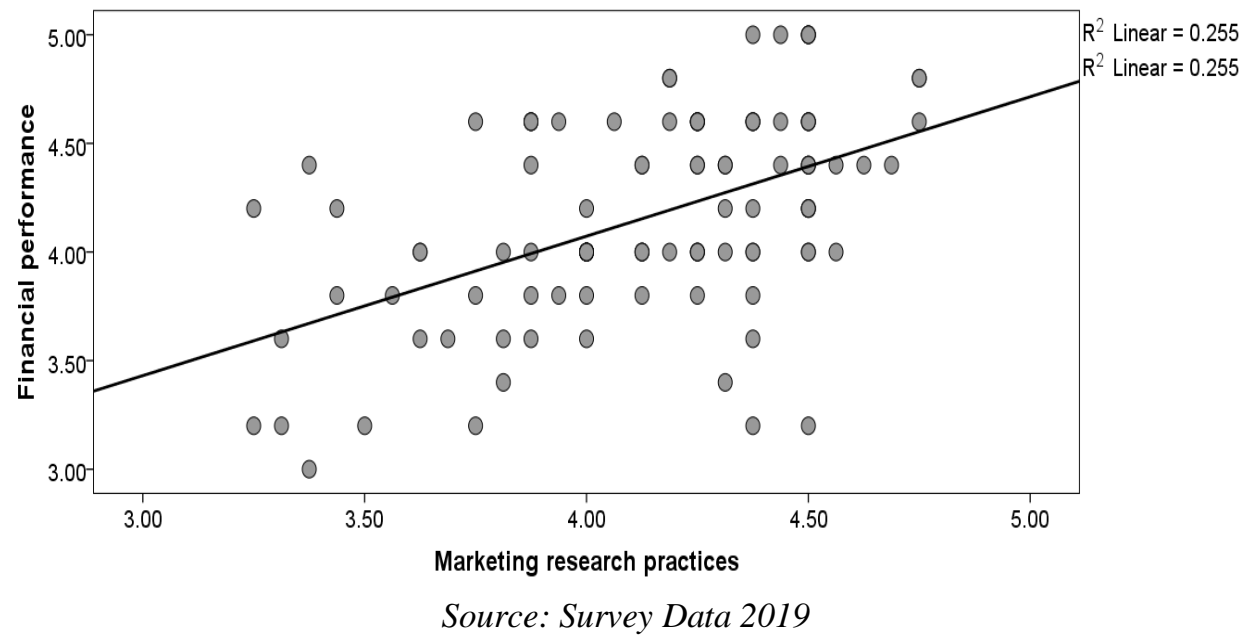

According to table 4.2, there is a moderate positive significant correlation between the Product related practices, maintain customer relationship related practices, and Price related practices with financial performance. But there is a weak positive significant correlation between the promotions related practices and financial performance.

\subsection{Regression Analysis}

Table 4.4 Multiple Regression analysis

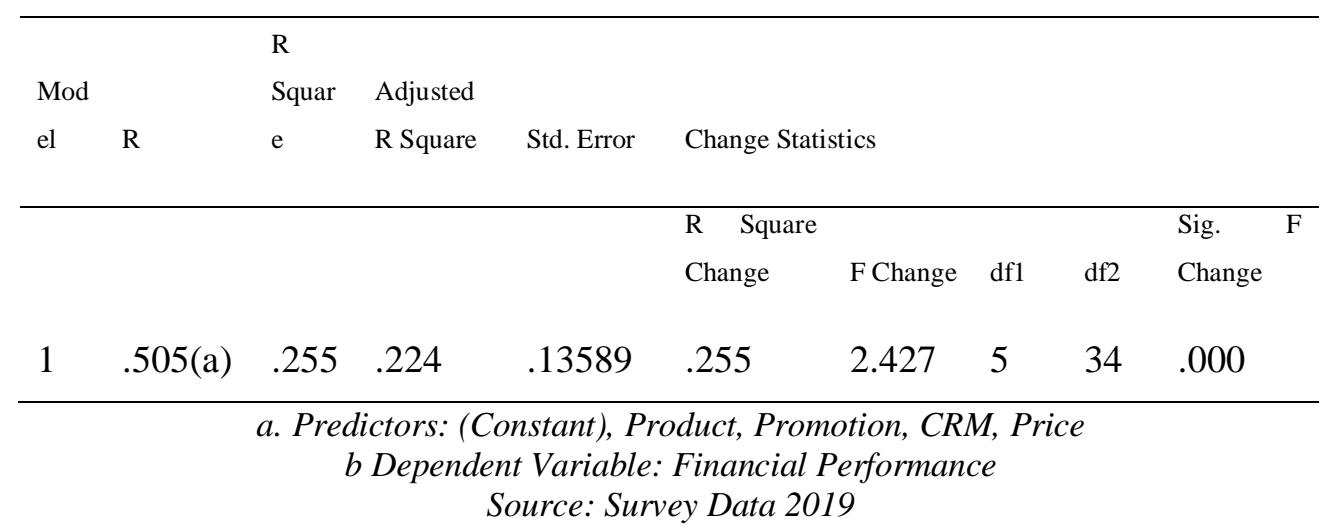


Table 4.5 Statistics of regression between MRP and FP

\begin{tabular}{llllll}
\hline & \multicolumn{2}{l}{ Unstandardized } & \multicolumn{2}{l}{ Standardized } & \\
Model & \multicolumn{2}{l}{ Coefficients } & Coefficients & $\mathrm{t}$ & \multicolumn{2}{l}{ Sig } \\
& $\mathrm{B}$ & Std. Error & Beta & & \\
\hline 1 (Constant) & .821 & .173 & & 4.756 & .000 \\
Product & .399 & .080 & .450 & 4.990 & .000 \\
Promotion & .262 & .088 & .290 & 2.996 & .000 \\
CRM & .285 & .084 & .325 & 3.408 & .001 \\
Price & .287 & .084 & .366 & 3.257 & .000 \\
\hline
\end{tabular}

Source: Survey Data 2019

In table $4.4, \mathrm{R}$ value has been recorded as .505 . $\mathrm{R}$ refer to the correlation between observed and predicted values of the independent variables. The $\mathrm{R}$ value range is -1 to +1 . And the sign of the $\mathrm{R}$ will show the direction of relationship between variables positive or negative as well. Therefore, it reveals that, there is a positive relationship among the variables and the relationship is a strong one as well.

The R Square value describes the proportion of variation in the dependent variable which is depended by the regression model. The value range of $\mathrm{R}$ Square is $0-1$. According to the research findings, $\mathrm{R}$ Square is recorded as .255 and it addresses that, there is a fit. As indicated by R Square, $25 \%$ of the variance of financial performance is explained by marketing research practices. This suggests that MRP has significantly explained $25 \%$ of the variance of financial performance.

According to the Table 4.5 , it is evident that all 4 variables' $\beta$ values are higher than zero $(0)$ and the significance level is also less than 0.05. At the same time, the Beta coefficient has a positive marking, supporting the direction of the hypothesis 2. i.e. There is a positive relationship between Marketing Research Practices and Financial Performance in SMEs of Sri Lanka. Hypothesis 1 is rejected since there is no negative relationship.

\section{DISCUSSION AND CONCLUSION}

The results of the study showed that level of marketing, research practices is in high level and level of financial performance also at high level. $25.5 \%$ variation in marketing research practices is explained by the financial performance of small and medium business and that is significant to conclude that the marketing research practices is good predictor of the financial performance and there is a moderate positive relationship between the marketing research practices and Financial Performance. The 
implication of the finding is the high level of marketing research practices positively correlate with financial performance.

As well as all the dimensions of the marketing research practices are significant predictors of the financial performance while product-related practices and price related practices are major among them. Most of the marketers think marketing research practices and business performance are positively related (Hooley \& Lynch, 1985; Braker \& Black, 1988). Bulut (2013), found the level of use of marketing research practices affect profitability and competitive standing. However, Gajanayake (2010), revealed that there is no significant impact of marketing strategies on their business growth by conducting a study on SMEs in Sri Lanka. This study confirms that a moderate positive relationship between marketing research practices and financial performance.

This study further confirms that there is a moderate positive significant correlation between productrelated practices and financial performance. Ebitu \& Tom (2016) found the significant impact of product quality strategy on the profitability and increased market share of SMEs. Lakhal \& Pasin (2008) identified the direct link between product quality and financial performance is not statistically significant. In addition, product quality has an indirect impact on financial performance.

This study also revealed that maintain customer relationship related practices, and Price related practices have significant relationships with financial performance. These were supported by previous studies. Ebitu \& Tom (2016) found the significant impact of relationship marketing strategy on profitability. Waskito (2018) indicated CRM highly influences on organizational profit. Also, Bhavani (2015) revealed CRM practices are useful to increase the profitability of businesses. According to Tony et al (2017), pricing policies influence profitability.

Among the 4 dimensions, only promotions related practices and financial performance are weakly positively correlated. Tandoh \& Sarpong (2015) conducted a study on automobile industries and revealed that impact of sales promotion on organizational performance is intense. But Nthenge (2016) conducted a study on clothing and footwear industry's SMEs and found only the promotion related practices (advertising) has a significant impact on a firm's performance.

\subsection{Recommendations and Implications}

To face the high competition, SMEs should follow marketing practices and actual information should be in hand. Therefore, there is a need to strengthen product related practices, provide and use high customer related practices, promotion and price related practices. It is proposed that SMEs in Rathnapura district should pay more attention on product related practices. If they provide quality product to their customers, they can increase their customer loyalty. Through that they can enhance 
financial performance (Adewale et al, 2013). SMEs in Rathnapura district should invest more on innovation, change competitive price and should more engage with after sales services. Offer benefits and product value that responds to the customer's desires.

To face the high competition, SMEs should increase their promotion related practices like advertising. A study by Adewale et al. (2013), revealed that the relationship between promotion consideration and business performance is significant. SMEs in Rathnapura district should increase promotion tools depend upon the type of product and the charged price for particular product. Maintaining marketing communication activity that correlates most with the business performance. In the customer relationship marketing practices being to create strong customer connections to a brand that can lead to ongoing business, free word-of-mouth promotion and information from customers that can generate leads (Rouse, 2015). They should treat customers as individuals who are respected and valued. Train and guide SME employees to make, attract and maintain their customer relationship in proper way.

The findings of this research study shall be important on the theoretical as well as on the practical level. As this research model proves to be an explanatory model of impact of marketing research practices on financial performance of small and medium scale business, the findings of this study are important to improve marketing research practices in order to increase financial performance among small and medium businesses in Rathnapura district.

This research study will help any future researchers who are interested to do a study in regarding with Impact of MRP and financial performance of small and medium scale businesses. The findings of this research will helps to government organizations as well as other organizations to understand the current states of small businesses in Rathnapura district with regarding new marketing research aspects and take further action to improve the present situation. They also can find out some other strategies to improve the marketing research practices of small and medium businesses as they are the drivers of development process of Sri Lanka.

Ultimately the findings of this research will help to various parties those who are interested to the relevant subject and decision makers to get proper decision regarding the small and medium scale businesses and also in order to build right strategy for Small and medium scale business to get right understanding about role of marketing research practices, its effectiveness and factors affecting the financial performance.

\subsection{Limitations}

Further investigation in small and medium businesses in other districts operating in Sabaragamuwa province and other provinces of Sri Lanka may provide additional insights into the findings of the study. 
Another important limitation is that this analysis is cross - sectional in nature. Additional research is suggested to be carried out longitudinally in order to evaluate the impact of variables over time. Longitudinal studies using both qualitative and quantitative techniques are required in order to understand the changes in the independent variable over time. Such studies could result in new explanatory variables.

Another limitation is that the sample has been taken to represent the population only on one basis, it is purposive / convenience sampling. The sample size had to be restricted only to 200 due to some problems. If the sample size are increased it would be able to obtain results with a lesser sampling errors. Finally, when financial performance analysis for a business it is important to examine and take in to account other sources of in addition to the financial statement and ratio analysis for the business and most small and medium scale business have low financial reports and disclose additional information.

\section{REFERENCES}

[1] Adewale, A., et al. (2013). Impact of Marketing Strategy on Business Performance A Study of Selected Small and Medium Enterprises. Journal of Business and Management, 59-66.

[2] Aktan, B., \& Bulut, C. (2008). Financial performance impacts of corporate entrepreneurship in emerging markets: A case of Turkey. European journal of economics, finance and administrative sciences, 69-79.

[3] Asha, O., (2017). Perceived Influence of Marketing Research Practices on Performance of Cement Manufactures in Kenya. Journal of Management and Economics, 72-81.

[4] Awan, A.G., \& Hashmi, S. (2014). Marketing Practices of Small \& Medium Size Enterprises: A Case Study of SME's in Multan District. European Journal of Business and Innovation Research, 9-20

[5] Bhavani, G., (2015). Impact of the customer relationship management practices on the profitability of UAE banks. Journal of Business Management \& Social Sciences Research4(6), 425-434

[6] Braker, H. M., \& Black, C. (1988). The competitiveness of british industry what realy makes the defference. European journal of marketing, 70-85.

[7] Bulut, D. A. (2013). Imapct of marketing research activities on marketing performance in textile companies. Journal of Managment Economic and Business, 260-269.

[8] Cateora, P. R., \& Graham, J. (2005). Internationla marketing. New York: Margraw Hill Compan. 
[9] Chandler, G. N., \& Hanks, S. H. (1993). Measuring the performance of emerging businesses. Journal of business venture, 391-408.

[10] Davies, T. (2000). Markeing research and devo;oping a marketing plan. Regional business center.

[11] Dushi, N.S., et al. (2019). Entrepreneurial marketing dimensions and SMEs performance. Journal of business research100:86-99.

[12] Ebitu, \& Tom, E. (2016). Marketing strategies and the performance of small and medium enterprises in akwa ibom state, Nigeria. british journal of marketing studies4(5): 51-62.

[13] Forsaith, D., \& Hall, J. (2000). Financial Performance and the Size of a Business Proceedings of 45th ICSB World Conference 'Entrepreneurial SME's. International Council for Small Business.

[14] Department of Census and Statistics. (2014). Non-Agricultural Economic Activities in Sri Lanka Economic Census: Retrieved from http://www.statistics.gov.lk/Economic/Economic\%20Census.html

[15] Galagoda, S. (2008). SMEs Play Critical Role in a Country's Economy, Sunday Observer. Colombo.

[16] Gamage, A. (2003). Small and medium enterprise development in Sri Lanka. 133-150.

[17] Hair, J. F., et al. (1998). Multivariate Data Analysis (5th Edn), Prentice Hall: New Jersey.

[18] Harvad. (2007). An investigetion in to the impact of marketing research. Uk journal.

[19] Hendricks, K.B., \& Singhal, V.R. (2001). Firm characteristics, total quality management, and financial performance. Journal of Operations Management, 19, 269-285.

[20] Hooley, G., \& Lynch, J. (1985). Marketing lesson from UL's high flying companies. Journal of marketing managment, 43-59.

[21] Lakhal, L., \& Pasinb, F. (2008). The direct and indirect impact of product quality on financial performance: A causal model. Total quality management and business excellence19(10):10871099.

[22] Learnmarketing. (2015). The marketing mix: product strateg. Retrieved from www.learnmarketing.net/product.htm.

[23] Mba, \& Emeti. (2014). Challange and prospect of small and medium scal business. Journal of Europen, $101-114$.

[24] Moses, T. P. (2015). An exploratory study of the strategic marketing practices of ICT firm in India. Wellington: Massey university. 
[25] Nthenge, D. M. (2016). Relationship between Marketing Practices and Firm Performance.

[26] Raguragavan, G. (2001). The Relationship between Market Research and Business Performance: Massey University.

[27] Rambocas, M., \& Gama, J. (2013). Marketing Research:The Role of Sentiment Analysis. School of Economic and managment, 14.

[28] Rouse, M. (2015). Relationship marketing definition. Retrieved from http://searchcrm.techtarget.com/definition/relationship-marketing

[29] Tandoh, I., \& Sarpong, L. (2015). The impact of sales promotions on the performance of automobile industries in Ghana. European journal of business and management 7(11):176-195.

[30] Tony, D., et al. (2017). Pricing strategies and levels and their impact on corporate profitability. Revista de Administração52:120-133.

[31] Tony, P., \& Jamieson, B. (2012). Marketing Research. Edinburgh Business School, 9-13.

[32] Vijayakumar, S. (2013). The status of small and medium enterprises and promotions for their growth in srilanaka. international journal on global business management and research11(2)

[33] Waskito, S., (2018). The Impact of Customer Relationship Management on Organization Profit of in Somali. Journal of entrepreneurship \& organization management7(1)

[34] Zikmund, W.G., \& Babin, B. (2010). Essentials of Marketing research. Cengage Learning, 1920. 